\title{
VALIDATION OF THE MALAY VERSION OF THE CANCER THERAPY SATISFACTION QUESTIONNAIRE AMONG MALAYSIAN CANCER PATIENTS
}

\author{
Norhaliza Abd Hamid ${ }^{1}$, Nur Amirah Hamdan ${ }^{1}$, Nizuwan Azman ${ }^{2}$ and Mohammad Farris Iman Leong Bin \\ Abdullah ${ }^{1}$ \\ 'Lifestyle Science Cluster, Advanced Medical and Dental Institute, Universiti Sains Malaysia, SAINS@BERTAM, 13200 \\ Kepala Batas, Pulau Pinang, Malaysia. \\ ${ }^{2}$ Division of Research and Networking, Advanced Medical and Dental Institute, Universiti Sains Malaysia, 13200 Kepala \\ Batas, Pulau Pinang, Malaysia.
}

\author{
Corresponding author: Mohammad Farris Iman Leong Bin Abdullah \\ Email: farris@usm.my
}

\begin{abstract}
Satisfaction with treatment among cancer patients is vital for planning of healthcare strategies and to ensure compliance to cancer therapy. Hence, this study translated the original English version of the Cancer Therapy Satisfaction Questionnaire (CTSQ) into Malay and investigated the reliability and validity of the Malay version for use to assess satisfaction with treatment among Malaysian cancer patients. Initially, concurrent translation and back translation of the English version of the CTSQ was performed. Then, the Malay version of the CTSQ (CTSQ-M) was administered to 200 cancer patients with different sites and stages of cancer for assessment of its reliability and validity. The CTSQ-M and its domains exhibited acceptable internal consistency (Cronbach's a ranged from 0.724 to 0.882 ). Convergent and discriminant validity were achieved by the CTSQ-M. Construct validity was achieved by the CTSQ-M as exploratory factor analysis extracted 3 factors, while confirmatory factor analysis confirmed that the CTSQ$M$ consisted of 16 items in 3 domains. We concluded that the CTSQ-M had acceptable psychometric properties.
\end{abstract}

Keywords: Awareness, Reliability and validity, validation study, cancer, Malaysia.

\section{INTRODUCTION}

Cancer is a life-threatening illness which must be treated with surgery, chemotherapy, and radiotherapy that are associated with numerous adverse effects and may affect the satisfaction with treatment among cancer patients. Satisfaction with treatment has become an important assessment in cancer patients as it affects the decision of healthcare facilities on its treatment plan and operational procedures. ${ }^{1}$ By assessing the satisfaction with treatment among cancer patients, healthcare facilities could instill improvement to overcome the deficiency which leads to poor satisfaction among cancer patients and improve their quality of life. ${ }^{2}$ Besides, due to various side effects of cancer treatment, this often affect their satisfaction with treatment and in turn reduce compliance of patients to treatment. $^{3}$ Hence, assessment of patient's satisfaction with treatment will allow various associated factors to be identified and in turn help to plan for treatment strategies to improve treatment adherence. Satisfaction of cancer treatment has been assessed in patients of various sites of cancer, such as breast, lung, colorectal, prostate, and ovarian cancer. ${ }^{4-6}$

There are a few instruments which are design to measure patients' satisfaction with treatment received, such as the Treatment Satisfaction Questionnaire for Medication (TSQM), ${ }^{7}$ the Satisfaction with Asthma Treatment Questionnaire (SATQ), ${ }^{8}$ and the European
Organisation for Research and Treatment of Cancer satisfaction with cancer care core questionnaire (EORTC PATSAT-C33). ${ }^{9}$ The TSQM is a generic self-reported instrument developed for general assessment of convenience, effectiveness, side effects, and global satisfaction of treatment of chronic illnesses with medication and has not been validated in cancer patients. ${ }^{7}$ While the SATQ is more specific for assessment of treatment satisfaction in bronchial asthma patients and has not been adapted for assessment of treatment satisfaction in cancer patients. ${ }^{8}$ The EORTC PATSAT-C33 is more specific for assessing health-related quality of life (HRQoL) among cancer patients. ${ }^{9}$ Nevertheless, it does not address cancer patients' satisfaction, expectation, and preference regarding the occurrence and management of side effects of cancer treatment, their choice and type of cancer therapy, and their perceived efficacy of cancer treatment. These information are pivotal for treating clinicians to plan for prevention and management of cancer treatment side effects to enhance the treatment adherence of patients and ultimately, further enhanced the HRQoL of cancer patients.

The Cancer Therapy Satisfaction Questionnaire (CTSQ) is the only instrument available to specifically assess the expectation and satisfaction of cancer treatment, and the expectation of the side effects of cancer 
treatment received. However, the CTSQ only assess cancer patients with chemotherapy or biological therapy in the form of pills or IV route of administration, it does not assess cancer patients treated with radiotherapy and/or surgery. ${ }^{10-12}$ The validity of the different domains of the CTSQ to assess the expectation of treatment, feeling with side effects, and satisfaction of treatment was evaluated by comparing the scores of the CTSQ domains with the appropriate known-groups validity criteria, such as stage of cancer, perceived change in cancer, ECOG performance status, and presence or absence of medication side effects of the cancer participants, calculated as minimally important difference (MID). The findings indicated more agreement than disagreement between the CTSQ domains and the appropriate known-groups validity criteria. ${ }^{10}$

To the best of our knowledge, the CTSQ has been translated and validated in Korean ${ }^{11}$ and Dutch. ${ }^{12}$ The validation study of the Korean version of the CTSQ demonstrated good internal consistency of the domains with Cronbach's a ranged from 0.740.86 and exploratory factor analysis (EFA) revealed that the tool consisted of three factors, which were satisfaction with therapy (SWT), feelings about side effects (FSE), and expectation of therapy (ET), similar to the original English version of the CTSQ, except the SWT domain had only six items instead of seven items in the original English version of the CTSQ, as item 9 recorded low factor loading $(<0.4) .{ }^{11}$ The validation study of the Dutch version of the CTSQ demonstrated good internal consistency of all its domains (Cronbach's a ranged from 0.77 to 0.83 ) and EFA indicated that the SWT domain had seven items, FSE domain had four items, and ET domain had five items similar to the original English version of the CTSQ. Item 8 was also reported to demonstrate almost equal factor loading with the SWT and ET domains, similar to that of the original English version of the CTSQ. ${ }^{12}$ This study aimed to translate the original English version of the CTSQ into the Malay language and investigate the reliability and validity of the Malay version for use to assess satisfaction with treatment among Malaysian cancer patients.

\section{METHODS}

\section{Study design}

This validation study was conducted from October 2019 to August 2020 for a period of ten months. Participants were recruited from the Oncology outpatient clinic, daycare, and inpatient ward of a tertiary referral centre for oncology located in northern Peninsular Malaysia with an oncology patient load of 2500 to 3000 patients. The estimated sample size required for the study was calculated according to:

(i) Calculation of sample size for internal consistency using the Statstodo Programme: probability of type I error $=0.05$, power $=1-B=$ 0.8 , expected Cronbach's $\alpha=0.95 .{ }^{13}$ Hence, the sample size required for each item $=4$ subjects. Total number of items $=16$. Therefore, estimated sample size required $=4 \times 16=64$ subjects.

(ii) Calculation of sample size for exploratory factor analysis was based on the Rule of 5 which states that one's sample should be at least five times the number of variables to be studied. ${ }^{14}$ Hence, the subjects-to-variables ration should be 5 or greater. The total number of items was 16 items. Therefore, estimated sample size needed= $16 \times 5=80$ subjects.

(iii) Calculation of sample size for confirmatory factor analysis was based on the validation study of the original English version of the CTSQ by Trask et al. (2008) ${ }^{10}$ and calculated using A-priori Sample Size calculator for Structural Equation Models: Effect size: 0.3, power: 0.8, latent variables: 3 , observed variables: 16 , a err prob: 0.05 . Hence, the total sample size needed was 123 subjects.

Based on all three calculations, the largest sample size required was 123 subjects, hence the final estimated sample size required for this study was $123+24$ (adding 20\% drop out rate) $=147$ subjects.

Participant recruitment was carried out via consecutive sampling. The sampling frame was cancer patients diagnosed with any cancer types registered under the oncology unit of the targeted tertiary referral centre who fulfilled all eligibility criteria of the study. Cancer patients were approached and explained regarding the study objectives and procedures, and then screened for eligibility criteria. The eligibility criteria were: (1) those who were diagnosed with any cancer types with reference to the histopathological examination report regardless of the stage of cancer and duration of diagnosis (except for those with brain tumour or metastasis to the brain who were excluded), (2) those who can read and write in Bahasa Malaysia, (3) those who were 18 years and above, and (4) those who were physically capable to answer the questionnaires. Patients who fulfilled all eligibility criteria were invited to participate in the study voluntarily, were assured of anonymity, and written informed consent for study participation were signed according to the Declaration of Helsinki (human ethics approval: USM/JEPeM/18100483). Eventually, a total of 200 participants were recruited for the study. Then, the participants were administered with sociodemographic and clinical characteristics questionnaires, the Malay version of the Cancer Therapy Satisfaction Questionnaire (CTSQ-M), and the Malay version of the 12-item Fear of Progression Questionnaire-Short Form (FoP-Q-M). The latter questionnaire was used as a comparison for the CTSQ-M to assess discriminant validity. All 200 participants completed the study questionnaires without any missing data. Hence, the sample size recruited in the study was more than the estimated minimal sample size required 
for the study. Furthermore, Terwee et al. (2007) suggested that a minimal sample size of 50 subjects would be sufficient for measuring psychometric properties of health status questionnaires. ${ }^{15}$

\section{Translation and back translation of the Cancer} Therapy Satisfaction Questionnaire (CTSQ)

The CTSQ was translated into Malay by a native Malay bilingual language expert from the School of Language and Literacy, Universiti Sains Malaysia and back-translated to English by a native English bilingual language expert from the same school who has never seen the original English version of the CTSQ and not in contact with the native Malay bilingual language expert. Then, the translated and back-translated drafts of the CTSQ were examined by a group of content experts (consist of 2 oncologists and 1 psychiatrist) to draft the Malay version of the CTSQ (CTSQ-M). The content validity index (CVI) was calculated, where the item-CVI (I-CVI) and the Scale-level-CVI (S-CVI) were computed. The item-CVI or I-CVI was calculated as the number of experts who gave a rating of "very relevant" to each item of the CTSQ-M divided by the total number of experts, in which I-CVI of $>0.79$ indicated that the item is relevant. The Scalelevel-CVI (S-CVI) consists of two types, which are the Universal Agreement (UA) among experts (S$\mathrm{CVI} / \mathrm{UA}$ ) and the Average CVI (S-CVI/Ave). The S$\mathrm{CVI} / \mathrm{UA}$ is computed by the sum of all the items with I-CVI equal to 1 divided by the total number of items of the CTSQ-M, while the S-CVI/Ave is the sum of I-CVIs divided by the total number of items of the CTSQ-M. ${ }^{16}$ A S-CVI/UA of $\geq 0.8$ and a S$\mathrm{CVI} /$ Ave of $\geq 0.9$ denoted excellent content validity. ${ }^{17}$ The $\mathrm{I}-\mathrm{CVI}$ of the CTSQ-M was 1.0 , the $\mathrm{S}$ $\mathrm{CVI} / \mathrm{UA}$ was 1.0 , and the S-CVI/Ave was also 1.0.

The drafted CTSQ-M was administered to 20 cancer patients who were native speaker of the Malay language in a pilot study to assess the face validity of the questionnaire. Then, they were interviewed and asked to rate on the wording and sentence structure, comprehensibility of the content, semantic quality of the content, and the duration of administration, whether these parameters were "very sufficient", "sufficient" or "insufficient". The pilot study participants were not included in the final sample of the study.

The findings revealed that $70 \%$ of the cancer participants agreed that the wording and sentence structure, comprehensibility of content, semantic quality of the content, and the duration of administration were "sufficient", while $30 \%$ of the participants agreed that these variables were "very sufficient". None of the participants perceived that the variables assessed were "insufficient". Hence, further amendment of the CTSQ- $M$ by the team of experts was not necessary. A copy of the Malay version of the CTSQ (CTSQ-M) is included in the supplementary file.

\section{Measures}

The socio-demographic and clinical characteristics questionnaire was administered to collect data on the socio-demographic characteristics of the participants (such as age, gender, ethnicity, religion, monthly income, marital status, and education status) and the clinical characteristics (such as diagnosis of the type of cancer, stage of cancer, and duration of diagnosis of cancer). The socio-demographic data were collected through the self-reported responses of the participants, while clinical data were obtained from the clinical records of the participants.

The Cancer Therapy Satisfaction Questionnaire (CTSQ) is a self-administered tool for assessment of the experience of cancer patients with regards to the therapies they received for treating their illness and how satisfied are they to the therapies they received. It consists of 16 items in three domains (satisfaction with therapy [SWT], feelings about side effects [FSE], and expectation of therapy [ET]). There are 5 items under expectation of therapy, 4 items under feelings about side effects, and 7 items under satisfaction with therapy. Each item was scored in a Likert scale from 1 (associated with the worse response) to 5 (associated with the best response). Four items were reverse-coded (items 5, 6, 9, and 11). The internal consistency (Cronbach's a) for the domains ranged from 0.77 to $0.87 .{ }^{10}$

The Fear of Progression Questionnaire-Short Form (FoP-Q-SF) is a self-administered tool for assessment of the degree of fear of cancer progression among cancer patients. It consists of 12 items in a single domain. ${ }^{18}$ In this study, the Malay version of the FoP-Q-SF (FoP-Q-SF-M) was used as a comparison for the CTSQ-M to assess its discriminant validity as both questionnaires are used for cancer patient assessment but they assessed different constructs.

\section{Statistical analysis}

Data analysis was performed using the Statistical Package for Social Sciences version 26 (SPSS version 26). Descriptive statistics were reported for socio-demographic and clinical characteristics of participants, and the CTSQ-M total and domain scores, in which categorial data were described in frequency and percentage, and continuous data in mean and standard deviation. Reliability was assessed with the internal consistency of the CTSQ-M by reporting the Cronbach's a of its total score and its domains. Cronbach's a of $>0.7$ was considered as acceptable. The convergent validity of the CTSQ-M was examined by comparing the Pearson's correlation coefficient of each item with its designated domain and non-designate domains. The discriminant validity of the CTSQ-M was assessed by the Pearson's correlation coefficient of each domain of the CTSQ-M with the FoP-Q-SF-M. The construct validity was measured by exploratory factor analysis (EFA) and 
confirmatory factor analysis (CFA). EFA included assessment of the Kaiser-Meyer-Olkin measure of sample adequacy (with value of $>0.6$ considered as good factor analysis), the Barlett's test of sphericity (with statistical significance at $p<0.05$ considered as valid analysis), factor extraction (in which only factor(s) with eigenvalue of $>1.0$ was retained), factor rotation with Varimax rotation, and factor loading of each item (only factor loading of $>0.4$ was considered as adequate). CFA checked for correlated errors between items was performed by using the IBM Analysis of Moment Structure (AMOS) version 25 to determine the best-fitting model of the CTSQ-M. In CFA, the following variables were taken into consideration for identifying the best-fitting factor model: chi- square with $p>0.05$ was considered as acceptable, comparative fit index (CFI) where $\geq$ 0.95 was considered as acceptable, Tucker-Lewis index (TLI) where $\geq 0.95$ was considered as acceptable, goodness of fit index (GFI) in which $\geq$ 0.90 was taken as acceptable, standardized rootmean-square residual (SRMR) where between 0.05 to 0.08 was taken as acceptable, and root mean square error of approximation (RMSEA) where < 0.06 was taken as acceptable. ${ }^{19}$

\section{RESULTS}

\section{Participants}

The Socio-demographic and clinical characteristics of the participantsin Table 1.

Table 1: The socio-demographic and clinical characteristics of the participants

Variables Number of participants

(n)

Age:

18-24 years

25-45 years

46-65 years

$>65$ years

Gender:

Male

Female

Ethnicity:

Malays

Chinese

Indians

Others

Monthly income:

$\leq$ RM 3000

RM 3001-RM 5000

$>$ RM 5000

Marital status:

Married

Single/divorcee/widow/widower

Education status:

Primary education

Up to secondary education

Tertiary education and above

Site of cancer:

Breast carcinoma

Nasopharyngeal carcinoma

Lung cancer

Colorectal carcinoma

Others

Duration of diagnosis:

New case

$<1$ year of diagnosis

$\geq 1$ year of diagnosis

Stage of cancer:

Stage 1

Stage 2

Stage 3

Stage 4

CTSQ score:

Mean of expectation of therapy

Mean of feelings of side effects

Mean of satisfaction with therapy

Mean of total CTSQ score

${ }^{a}$ Mean, ${ }^{b}$ standard deviation
6

52

119

23

73

127

153

22

21

4

144

32

24

178

22

24

91

85

100

19

24

50

7

25

94

81

21

91

46

42

$20.89^{a}$

$14.15^{\mathrm{a}}$

$27.50^{\mathrm{a}}$

$59.32^{\mathrm{a}}$
Percentage

(\%)

3.0

26.0

59.5

11.5

36.5

63.5

76.5

11.0

10.5

2.0

72.0

16.0

12.0

89.0

11.0

12.0

45.5

42.5

50.0

9.5

12.0

25.0

3.5

12.5

47.0

40.5

10.5

45.5

23.0

21.0

$4.30^{\mathrm{b}}$

$3.14^{\mathrm{b}}$

$3.91^{\mathrm{b}}$

$6.95^{\mathrm{b}}$ 
Reliability and validity of the CTSQ-M Assessment of the reliability of the CTSQ-M indicated that the internal consistency of the total score of the CTSQ-M had a Cronbach's a of 0.854 . The internal consistency of all the domains of the CTSQ-M were as followed: Cronbach's a of ET was 0.882 , Cronbach's a of FSE was 0.724 , and Cronbach's a of SWT was 0.752. Convergent validity of the CTSQ-M indicated that items 1,2 , 3,4 , and 8 had the highest Pearson's correlation coefficient with their designated domain (ET) compared to their correlations with nondesignated domains. Similarly, items 5, 6, and 11 had the highest Pearson's correlation coefficient with their designated domain (FSE) compared to their correlations with non-designated domains. Nevertheless, item 13 had higher correlation with the SWT domain compared to its correlation with its own designated domain (FSE). Items 9, 10, 12, 14,15 , and 16 had the highest correlations with their designated domain (SWT) compared to their correlations with non-designated domains. On the contrary, item 7 had higher correlation with the ET domain compared to its correlation with its own designated domain (SWT). Table 2 illustrates the Pearson's correlation coefficient between items and domains of the CTSQ-M. Discriminant validity assessment demonstrated that all the domains of the CTSQ-M had only low correlations with the FoP-Q-SF-M. The Pearson's correlation coefficient between ET domain of the CTSQ-M and the FoP-Q-SF-M was $0.209(p<0.05)$, between FSE domain of the CTSQ-M and the FoP-Q-SF-M was $0.281(p<0.05)$, and between SWT domain of the CTSQ-M and the FoP-Q-SF-M was $-0.230(p<0.05)$.

Table 2a: Pearson's correlation coefficient between items and domains within the CTSQ-M Items

Expectation of therapy

Item 1 (In general, in the last four weeks, how often did you feel that cancer therapy (IV/pills) would help you to return back to a normal life?)

[Pada keseluruhannya, dalam empat minggu yang terkini, berapa kerapkah anda berpendapat bahawa rawatan kanser (IV/pil) membantu anda untuk kembali kepada kehidupan normal?]

Item 2 (In general, in the last four weeks, how often did you feel that cancer therapy (IV/pills) would get rid of the cancer?)

[Pada keseluruhannya, dalam empat minggu yang terkini, berapa kerapkah anda berpendapat bahawa rawatan kanser (IV/pil) berjaya merawat kanser anda?]

Item 3 (In general, in the last four weeks, how often did you feel that cancer therapy (IV/pills) would prevent the cancer from coming back?)

[Pada keseluruhannya, dalam empat minggu yang terkini, berapa kerapkah anda berpendapat bahawa rawatan kanser (IV/pil) membantu untuk mencegah kanser anda daripada berulang?]

Item 4 (In general, in the last four weeks, how often did you feel That cancer therapy (IV/pills) would stop the cancer from spreading?)

[Pada keseluruhannya, dalam empat minggu yang terkini, berapa kerapkah anda berpendapat bahawa rawatan kanser (IV/pil) akan mencegah kanser anda daripada merebak?]

Item 8 (In general, in the last four weeks, how often did you feel that cancer therapy (IV/pills) would help you live longer?) [Pada keseluruhannya, dalam empat minggu yang terkini, berapa kerapkah anda berpendapat bahawa rawatan kanser (IV/pil) dapat membantu anda untuk hidup lebih lama?]

Item 5R (In general, in the last four weeks, how often did you feel That your cancer therapy (IV/pills) limited your daily activities?) [Pada keseluruhannya, dalam empat minggu yang terkini, berapa kerapkah anda berpendapat bahawa rawatan kanser (IV/pil) menghadkan aktiviti harian anda?]
$0.791^{*}$
$-0.102$
$0.568^{*}$

Feelings Satisfaction about with therapy side effects

$0.851^{*} \quad-0.153^{*} \quad 0.626^{*}$

$0.844^{*}-0.141^{*} \quad 0.496^{*}$

$\begin{array}{lll}0.867^{*} & -0.119 & 0.480^{*}\end{array}$

$\begin{array}{lll}0.780^{*} & 0.006 & 0.498^{*}\end{array}$

$-0.118 \quad 0.820^{*}$

$-0.097$ 
Table 2b: Pearson's correlation coefficient between items and domains within the CTSQ-M

\begin{tabular}{lll}
\hline Items & $\begin{array}{l}\text { Expectation } \\
\text { of therapy }\end{array}$ & $\begin{array}{l}\text { Feelings } \\
\text { about } \\
\text { side }\end{array}$ \\
& effects
\end{tabular}

Item 6R (In general, in the last four weeks, how often did you feel upset about the side effects?)

[Pada keseluruhannya, dalam empat minggu yang terkini, berapa kerapkah anda berpendapat bahawa saya kecewa dengan kesan sampingannya?]
$-0.140^{*}$
$0.783^{*}$
$-0.200^{*}$

Item 11R (Overall, was taking cancer therapy (IV/pills) as difficult as you expected?)

[Secara keseluruhan, adakah rawatan kanser anda (IV/pil) menyusahkan seperti yang anda jangkakan sebelum rawatan?]
$0.173^{*}$
$0.621^{*}$
$0.430^{*}$

Item 13 (Overall, were the side effects of cancer therapy (IV/pills) as you expected?)

[Secara keseluruhan, adakah kesan sampingan rawatan

$0.259^{*}$

0.005

$0.513^{*}$

kanser anda (IV/pil) seperti apa yang anda jangkakan?]

Item 7 (In general, in the last four weeks, how often did you feel that cancer therapy (IV/pills) was worth taking even with the side effects?)

[Pada keseluruhannya, dalam empat minggu yang terkini, berapa kerapkah anda berpendapat bahawa rawatan kanser (IV/pil) berbaloi diambil walaupun terdapat kesan sampingan?]

Item 9R (In general, in the last four weeks, how often did you think about stopping your cancer therapy (IV/pills)?) [Secara keseluruhan, dalam empat minggu yang terkini, berapa kerapkah anda terfikir untuk menamatkan rawatan kanser anda (IV/pil)?]

Item 10 (Overall, how worthwhile was your cancer therapy (IV/pills)?)
$0.521^{*}$
$-0.162^{*}$
$0.728^{*}$

rawatan kanser anda (IV/pil)?]

Item 12 (Overall, how well did the benefits of the cancer therapy (IV/pills) meet your expectations?)

[Secara keseluruhan, berapa banyakkah rawatan kanser anda

$0.679^{*}$

$0.200^{*}$

$0.602^{*}$

(IV/pil) membawa faedah kepada anda?]

Item 14 (How satisfied were you with the form of your cancer therapy (IV/pills)?

[Adakah anda berpuas hati dengan jenis rawatan kanser

$0.562^{*}$

(IV/pil) yang anda terima?]

Item 15 (Overall, how satisfied were you with your most recent cancer therapy (IV/pills)?)

[Secara keseluruhan, adakah anda berpuas hati dengan rawatan kanser anda (IV/pil) yang terkini?]

Item 16 (Taking everything into consideration, if given the choice again, would you decide to take this cancer therapy treatment?)

[Dengan ambil kira semua faktor, jika diberi pilihan rawatan sekali lagi, adakah anda akan mengambil keputusan untuk menerima rawatan yang sama?] 
Table 3. Exploratory factor analysis with Varimax rotation and Kaiser normalization for the CTSQ-M

\begin{tabular}{cccc}
\hline Items & $\begin{array}{c}\text { Expectation of } \\
\text { therapy }\end{array}$ & $\begin{array}{c}\text { Feelings about } \\
\text { side effects }\end{array}$ & $\begin{array}{c}\text { Satisfaction with } \\
\text { therapy }\end{array}$ \\
\hline Item 1 & 0.757 & & \\
Item 2 & 0.815 & & \\
Item 3 & 0.778 & & \\
Item 4 & 0.840 & \\
Item 7 & 0.756 & & \\
Item 8 & 0.797 & 0.814 & \\
Item 5R & & 0.832 & \\
Item 6R & & 0.417 & 0.516 \\
Item 9R & & & 0.733 \\
Item 10 & & & 0.512 \\
Item 11R & & & 0.671 \\
Item 12 & & & 0.611 \\
Item 13 & & & 0.630 \\
Item 14 & & 1.823 & 3.116 \\
Item 15 & & 11.391 & 19.473 \\
Item 16 & & & 60.143 \\
Eigenvalue & & & \\
Variance (\%) & 4.685 & & \\
\hline
\end{tabular}

Table 4. Confirmatory factor analysis of three different models of the Malay version of the Cancer Therapy Satisfaction Questionnaire (CTSQ-M)

\begin{tabular}{|c|c|c|c|}
\hline Variables & $\begin{array}{l}\text { 4-factor model of the } \\
\text { CTSQ-M }\end{array}$ & $\begin{array}{l}\text { 3-factor model of the } \\
\text { CTSQ-M (similar to the } \\
\text { original English } \\
\text { version) }\end{array}$ & $\begin{array}{l}\text { 3-factor model of the } \\
\text { CTSQ-M (as suggested } \\
\text { by exploratory factor } \\
\text { analysis) }\end{array}$ \\
\hline Chi-square & $\mathrm{p}<0.05$ & $p<0.05$ & $p<0.05$ \\
\hline $\begin{array}{l}\text { Comparative fit index } \\
\text { (CFI) }\end{array}$ & 0.903 & 0.905 & 0.956 \\
\hline $\begin{array}{l}\text { Goodness of fit index } \\
\text { (GFI) }\end{array}$ & 0.864 & 0.875 & 0.910 \\
\hline Tucker-Lewis index (TLI) & 0.887 & 0.882 & 0.950 \\
\hline $\begin{array}{l}\text { Standardized root-mean- } \\
\text { square residual (SRMR) }\end{array}$ & 0.075 & 0.095 & 0.061 \\
\hline $\begin{array}{l}\text { Root mean square error } \\
\text { of approximation } \\
\text { (RMSEA) }\end{array}$ & 0.087 & 0.087 & 0.059 \\
\hline
\end{tabular}

Exploratory factor analysis (EFA) with Kaiser normalization and Varimax orthogonal rotation of the CTSQ-M reported a Kaiser-Meyer-Olkin measure of sampling adequacy of 0.861 and the Barlett's test of sphericity was statistically significant $(p<0.001)$ indicating that the EFA of the CTSQ-M was valid. A total of 3 factors was extracted for the CTSQ- $M$ with eigenvalue ranged from 1.823 to 4.685 which resulting in a total variance of $60.143 \%$. EFA revealed that the ET domain had 6 items, in which items 1, 2, 3, 4, 7, and 8 had excellent factor loading ranged from 0.756 to 0.840 . The FSE domain had only 3 items i.e. items 5,6 , and 9 which had factor loading ranged from 0.417 to 0.832 . Finally, the SWT domain had 7 items, where items 10 to 16 had factor loading ranged from 0.512 to 0.771 . The exploratory factor analysis of the CTSQ-M is summarized in Table 3.

Table 4 illustrates the confirmatory factor analysis of three different models of the Malay version of the Cancer Therapy Satisfaction Questionnaire (CTSQ-M). Confirmatory factor analysis (CFA) of the CTSQ-M revealed that a 4factor model of the CTSQ-M did not fit the data 
well (chi-square with $\mathrm{p}<0.05, \mathrm{CFI}=0.903, \mathrm{TLI}=$ $0.887, \mathrm{GFI}=0.864, \mathrm{SRMR}=0.075$, and RMSEA $=$ 0.087). A 3-factor model of the CTSQ-M in which items were allocated to domains according to what was suggested by the original English version of the CTSQ also did not fit the data well (chisquare with $\mathrm{p}<0.05, \mathrm{CFI}=0.905, \mathrm{TLI}=0.882, \mathrm{GFI}$ $=0.875$, SRMR $=0.095$, and RMSEA $=0.087$ ). Finally, a 3-factor model of the CTSQ-M which allocated items to domains according to what was suggested by the EFA findings of this study in which items $1,2,3,4,7$, and 8 were allocated to the expectation of therapy domain; items 5,6 , and 9 allocated to the feelings about side effects domain; and items 10,11, 12, 13, 14, 15, and 16 allocated to the satisfaction with therapy domain, was indicated as the best-fitting model (chisquare with $\mathrm{p}<0.05, \mathrm{CFI}=0.956, \mathrm{TLI}=0.950, \mathrm{GFI}$ $=0.910$, SRMR $=0.061$, and RMSEA $=0.059$ )

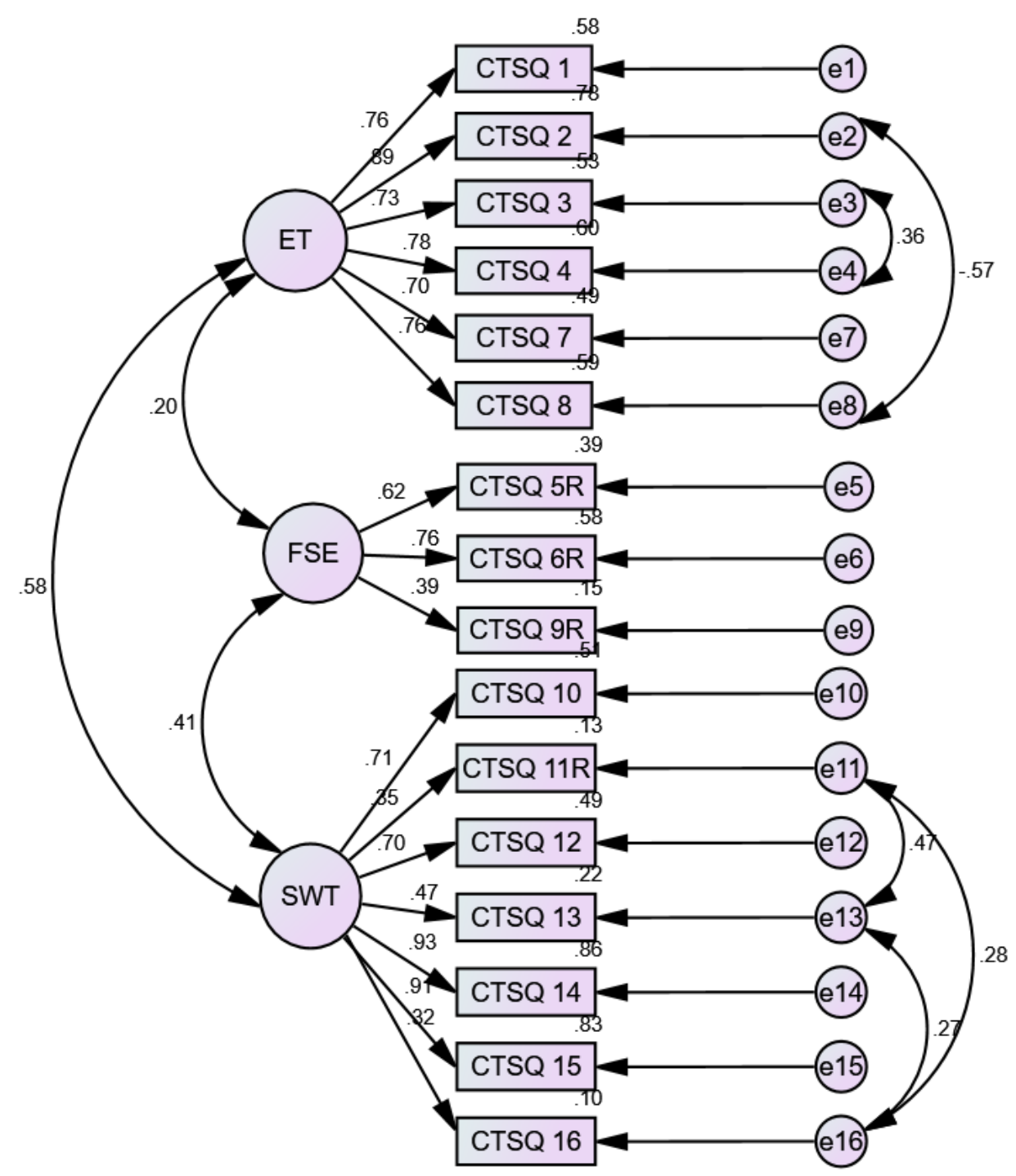

Figure 1. Confirmatory factor analysis of the CTSQ-M.

ET = expectation of therapy domain, FSE = feelings about side effects domain, SWT = satisfaction with therapy domain. CTSQ $1=$ item 1, CTSQ $2=$ item 2, CTSQ $3=$ item 3, CTSQ $4=$ item 4, CTSQ $5=$ item 5 , CTSQ 6 = item 6, CTSQ $7=$ item 7, CTSQ $8=$ item 8, CTSQ $11=$ item 11, CTSQ $13=$ item 13, CTSQ $14=$ item 14, CTSQ 15 = item 15, CTSQ 16 = item 16 


\section{DISCUSSION}

This study translated the original English version of the CTSQ to the Malay language and investigated the reliability and validity of the CTSQ-M. The internal consistency of all the domains of the CTSQ-M were acceptable with Cronbach's a of $>0.7 .{ }^{20}$ The internal consistencies of the domains and total CTSQ-M score (Cronbach's a ranged from 0.75 to 0.88 ) were comparable to that of the original English version of the CTSQ (Cronbach's a of its domains ranged from 0.77 to 0.87$)^{10}$ and of the Dutch version of the CTSQ (Cronbach's a ranged from 0.79 to $0.86),{ }^{12}$ but better than the internal consistency of the Korean version of the CTSQ (Cronbach's a ranged from 0.68 to 0.78$).{ }^{11}$ The discrepancy in internal consistency between the CTSQ-M in our study and that of the Korean version of the CTSQ could be explained by the different setting and methodology used. The validation study of the Korean version of the CTSQ recruited cancer patients who were treated with either traditional Korean medicine only or integration of traditional Korean medicine and Western medicine. Moreover, majority of the participants in the validation study of the Korean version of the CTSQ were in stage 4 of cancer (63.9\% to $86.0 \%)$. These differences may affect the findings of the validation study of the Korean version of the CTSQ.

The procedures employed in this study for translation and back-translation of the CTSQ as well as the construction of the CTSQ-M was based on the standard procedures to assess face and content validity recommended by the World Health Organization. ${ }^{21}$ In this study, since all the participants in the pilot study agreed that the clarity, semantic quality and comprehensibility of the words, instructions and sentence structures in the CTSQ- $M$ were acceptable, this demonstrated that the CTSQ-M had good face validity. ${ }^{21}$ With referral to the content validity index (CVI), the I$\mathrm{CVI}, \mathrm{S}-\mathrm{CVI} / \mathrm{UA}$, and $\mathrm{S}-\mathrm{CVI} /$ Ave were all 1.0, indicating excellent content validity. ${ }^{17}$ However, the content validity index was not assessed in the original English, Korean, and Dutch versions of the CTSQ; hence, comparison of their content validity findings with that of our study is not possible.

Convergent validity is achieved if the items in the questionnaire are highly correlated with their own designated domain but the items correlation with non-designated domains were low or nonsignificant. ${ }^{22}$ The CTSQ-M exhibited good convergent validity as all its items had significant and the highest correlation with its designated domain, except for items 7 and 13. On the contrary, discriminant validity of a questionnaire is indicated by absence or low correlations between the domains of the questionnaire under investigation and the domains of a comparison questionnaire which measures different constructs. $^{22}$ The CTSQ-M had acceptable discriminant validity as all its domains had low correlations with the FoP-Q-SF-M total score (Pearson's correlation coefficient ranged from 0.209 to 0.281 ).

Exploratory factor analysis of the CTSQ-M extracted 3 factors which was similar to that reported for the original English version, ${ }^{10}$ the Korean version, ${ }^{11}$ and the Dutch version of the CTSQ, ${ }^{12}$ but the number of items assigned to its domains were different in the CTSQ-M compared to the English, Korean, and Dutch versions of the questionnaire. In the CTSQ-M, the expectation of therapy domain had 6 items, feelings about side effects domain had 3 items, while the satisfaction with therapy domain had 7 items. Item 7 was assigned to the expectation of therapy domain instead of the satisfaction with therapy domain, item 9 was assigned to the feelings about side effects domain instead of satisfaction with treatment domain, while items 11 and 13 were assigned to the satisfaction with therapy domain instead of the feelings about side effects domain. Conversely, in the English and Dutch versions of the CTSQ, the expectation of therapy domain had 5 items, feelings about side effects domain had 4 items, while the satisfaction with therapy domain had 7 items. ${ }^{10,} 12$ While for the Korean version of the CTSQ, the expectation of therapy domain had 5 items, feelings about side effects domain had 4 items, while the satisfaction with therapy domain had 6 items ( 1 item was omitted). ${ }^{11}$

The discrepancy between the EFA findings of the CTSQ-M with that of the original English, the Dutch, and the Korean versions of the CTSQ could be due to differences in meaning of the items after they were translated into different languages. In the context of the CTSQ-M, when item 9 (In general, in the last four weeks, how often did you think about stopping your cancer therapy (IV/pills)?) was translated into Malay "Secara keseluruhan, dalam empat minggu yang terkini, berapa kerapkah anda terfikir untuk menamatkan rawatan kanser anda (IV/pil)?", the translated meaning of this item may lead to the participants to perceive that whether he/she may terminate the cancer therapy because of the severity of side effects which they need to endure during chemotherapy or IV or pill therapy. Hence, this may contribute to the factor loading of item 9 to be higher for the feeling about side effects domain, rather than for the satisfaction with treatment domain. As for item 11 (Overall, was taking cancer therapy (IV/pills) as difficult as you expected?), when translated into Malay "Secara keseluruhan, adakah rawatan kanser anda (IV/pil) menyusahkan seperti yang anda jangkakan sebelum rawatan?"; and item 13 (Overall, were the side effects of cancer therapy (IV/pills) as you expected?), when translated into Malay "Secara keseluruhan, adakah kesan sampingan rawatan kanser anda (IV/pil) seperti apa yang anda jangkakan?", the translated meaning of these items may lead to the participants to perceive 
that these two items assessed whether they were satisfied with the treatment which they received. Hence, this may contribute to the factor loadings of items 11 and 13 to be higher for the satisfaction with treatment domain, rather than for the feeling about side effects domain.

Ultimately, when the CFA was performed, it confirmed that the 3-factor model, in which the items were allocated to the domains according to what was suggested by the EFA findings of this study, whereby items $1,2,3,4,7$, and 8 were allocated to the expectation of therapy domain; items 5, 6, and 9 were allocated to the feelings about side effects domain; and items 10, 11, 12, $13,14,15$, and 16 were allocated to the satisfaction with therapy domain; was the best fitting model of the CTSQ-M (as shown in Table 4). Hence, the CFA findings of our study confirmed the findings in EFA. Although the best-fitting 16item 3-factor model shown in this study exhibited a significant chi-square $(p<0.05$, in which chisquare test in CFA measures the difference between the empirically found distribution of items in factors and the distribution of items in factors expected based on null hypothesis), if the sample size of the study is large enough, even small difference will lead to statistically significant chi-square. Furthermore, any models derived from any questionnaires are deemed to contain minor error. Hence, if the questionnaire is reliable and validated by large enough sample size, then minor error which leads to significant chi-square test in the CFA of the model is still acceptable. ${ }^{23}$ Calculation of the estimated sample size required in this study indicated that the total sample size of this study exceeded the estimated sample size required. In the validation studies of the original English, the Dutch, and the Korean versions of the CTSQ, CFA was not performed. ${ }^{10-12}$ Hence, to our best of knowledge, the CFA findings from our study was the first CFA performed on the CTSQ and it confirmed that the CTSQ may indeed contained 16 items in 3 domains, but with items $1,2,3,4,7$, and 8 designated to expectation of therapy domain; items 5,6 , and 9 allocated to the feelings about side effects domain; and items 10 , $11,12,13,14,15$, and 16 designated to the satisfaction with therapy domain.

There was a discrepancy between the findings on convergent validity and factor loading regarding item 11. Item 11 was found to be correlated well with its designated domain (feelings about side effects). However, in the subsequent EFA and CFA, it was found to be loaded to the satisfaction with therapy domain. In the assessment of convergent validity, although item 11 had the highest Pearson's correlation coefficient with the feeling about side effects domain $(r=0.621, p<$ 0.05), it also had quite a significant Pearson's correlation coefficient with the satisfaction with therapy domain $(r=0.430, p<0.05)$. But, Pearson's correlation coefficient $(r)$ is just a measure of the strength of the association between the two variables. EFA is a statistical technique that is used to reduce data to a smaller set of summary variables and to explore the underlying theoretical structure of the phenomena. It is used to identify the structure of the relationship between the variable and the respondent. CFA is a statistical technique used to verify the factor structure of a set of observed variables. In CFA, researchers can specify the number of factors required in the data and which measured variable is related to which latent variable. CFA is a tool that is used to confirm or reject the measurement theory. Hence, to decide on the number of factors which represent a specific construct and the item assignment to the factors, EFA and CFA are required. Pearson's correlation coefficient does not decide on item allocation to which factor. It only gives information on the measure of the strength of the association between the two variables (for example item 11 and the domain as in the CTSQM).

There were a few limitations of this study to take note of. First, this study did not assess the psychological and stress levels of the participants in which these factors may act as confounding factors which may influence the findings of the study. Second, in this study, $63.5 \%$ of the participants were female, $76.5 \%$ were Malays, $89 \%$ were married, and 50\% were diagnosed with breast cancer, which were not representative of the Malaysian cancer patient population, and hence, these affect the generalizability of our findings. Despite these limitations, the CTSQ-M had demonstrated adequate reliability and validity, and therefore it can be used for assessment of cancer therapy satisfaction, perception of treatment side effects, and expectation of the treatment received among the cancer population in Malaysia. These information are vital for treating clinicians to plan for management of treatment side effects to enhance adherence of cancer patients to the treatment regime.

\section{CONCLUSION}

This study successfully translated and validated the Malay version of the Cancer Therapy Satisfaction Questionnaire (CTSQ-M). The CTSQ-M exhibited acceptable to good internal consistency confirming its reliability, good face validity, good content validity with excellent CVI, and achieved convergent and discriminant validity. EFA indicated that the CTSQ-M had 3 domains and the CFA revealed that the CTSQ- $M$ had a best fitting 16-item 3-factor model which confirmed the findings of the EFA. The CTSQ-M is ready for use by treating clinicians and researchers to assess cancer treatment satisfaction among the Malaysian cancer population. 


\section{ACKNOWLEDGEMENT}

We wish to thank the staff nurses of the Oncology unit and the Otorhinolaryngology Clinic of Advanced Medical and Dental Institute, Universiti Sains Malaysia for their assistance in data collection.

\section{COMPETING INTEREST}

All the authors declare that there is no conflict of interest.

\section{FUNDING}

We wish to thank The Short Term Grant of Universiti Sains Malaysia for financial support and funding of this research project (304/CIPPT/6315236).

\section{SUPPLEMENTARY MATERIAL}

Supplementary Appendix 1. The Malay version of the Cancer Treatment Satisfaction Questionnaire (CTSQ-M)

\section{REFERENCES}

1. Crow R, Gage H, Hampson S, et al. The measurement of satisfaction with healthcare: implications for practice from a systematic review of the literature. Health Technol Assess 2002; 6(32):1-244.

2. Bergenmar $M$, Nylen $U$, Lidbrink $E$, et al. Improvements in patient satisfaction at an outpatient clinic for patients with breast cancer. Acta Oncol 2006; 45(5):550-8.

3. Abetz L, Coombs JH, Keininger DL, et al. Development of the cancer therapy satisfaction questionnaire: item generation and content validity testing. Value Health 2005; 8(Suppl 1):S41-S53.

4. von Gruenigen VE, Hutchins JR, Reidy AM, et al. Gynecologic oncology patients' satisfaction and symptom severity during palliative chemotherapy. Health Qual Life Outcomes 2006; 4:84.

5. Mathiesen TP, Willaing I, Frell M, et al. How do patients with colorectal cancer perceive treatment and care compared with the treating health care professionals? Med Care 2007; 45(5):394400.

6. Sherlaw-Johnson C, Datta P, McCarthy M. Hospital differences in patient satisfaction with care for breast, colorectal, lung and prostate cancers. Eur J Cancer 2008; 44(11):1559-65.

7. Bharmal M, Payne K, Atkinson MJ, et al. Validation of an abbreviated Treatment Satisfaction Questionnaire for Medication (TSQM-9) among patients on antihypertensive medications. Health Qual Life Outcomes 2009; 7:36.

8. Campbell JL, Kiebert GM, Partridge MR. Development of the Satisfaction with Inhaled Asthma Treatment Questionnaire. Eur Respir J 2003; 22:127-34.

9. Brédart A, Anota A, Young T, et al. Phase III study of the European Organisation for Research and Treatment of Cancer satisfaction with cancer care core questionnaire (EORTC PATSAT-C33) and specific complementary outpatient module (EORTC OUT-PATSAT7). Eur $J$ Cancer Care (Engl) 2018; 27(1).

10. Trask PC, Tellefsen C, Espindle D, et al. Psychometric validation of the cancer therapy satisfaction questionnaire. Value Health 2008; 11(4):669-79.

11. Park SJ, An SM, Kim SH. Development of a Korean version of the Cancer Therapy Satisfaction Questionnaire (CTSQ): crosscultural adaptation, reliability, and validity. Qual Life Res 2013; 22(2):431-6.

12. Cheung $\mathrm{K}$, de Mol M, Visser $\mathrm{S}$, et al. Reliability and validity of the Cancer Therapy Satisfaction Questionnaire in lung cancer. Qual Life Res 2016; 25(1):7180.

13. Ramli M, Mohd Ariff F, Khalid Y, et al. Validation of the Bahasa Malaysia version of the Coping Inventory for Stressful Situation. Malaysian Journal of Psychiatry Online 2008; 17(2):1-8.

14. Bryant FB, Yarnold PR. Principalcomponents analysis and exploratory and confirmatory factor analysis. In Grimm LG, Yarnold PR, eds. Reading and understanding multivariate statistics. Washington, DC: American Psychological Association 1995:99-136.

15. Terwee CB, Bot SDM, de Boer MR, et al. Quality criteria were proposed for measurement properties of health status questionnaires. J Clin Epidemiol 2007; 60(1):34-42.

16. Zamanzadeh V, Ghahramanian A, Rassouli $M$, et al. Design and implementation content validity study: development of an instrument for measuring patientcentered communication. J Caring Sci 2015; 4(5):165-78.

17. Shi J, Mo X, Sun Z. Content validity index in scale development. Zhong $\mathrm{Na} \mathrm{Da}$ Xue Xue Bao Yi Xue Ban 2012; 37(2):152-5. 
18. Mehnert A, Berg P, Henrich G, et al. Fear of cancer progression and cancer-related intrusive cognitions in breast cancer survivors. Psychooncology 2009; 18(12):1273-80.

19. Hu L, Bentler PM. Cutoff criteria for fit indexes in covariance structure analysis: conventional criteria versus new alternatives. Struct Equ Modeling 1999; 6(1):1-55.

20. Cicchetti DV. Guidelines, criteria, and rules of thumb for evaluating normed and standardized assessment instruments in psychology. Psychol Assess 1994; 6(4):284-90.

21. World Health Organization. Process of translation and adaptation of instruments. 2019 [Online] [Accessed 25 August 2020]. Available from https://www.who.int/substance_abuse/r esearch_tools/translation/en/.

22. Lua PL, Wong SY. The reliability of the Malay versions of hospital anxiety depression scale (HADS) and McGill quality of life questionnaire (MQOL) among a group of patients with cancer in Malaysia. Malaysian Journal of Psychiatry 2012; 21(1):1-13.

23. Prudon P. Confirmatory factor analysis as a tool in research using questionnaires: a critique. Comprehensive Psychology 2015; $4: 10$ 